\title{
A rare cause of urolithiasis in an infant: Questions
}

\author{
Mustafa Koyun $^{1}$ (D) Muhammet Sancaktar ${ }^{1}$ - Gülşah Kaya Aksoy ${ }^{1}$. Elif Çomak ${ }^{1}$ - Ayla Kaçar ${ }^{1} \cdot$ Mehtap Adar $^{1}$. \\ Afig Berdeli ${ }^{2} \cdot$ Sema Akman ${ }^{1}$
}

Received: 2 December 2020 / Accepted: 17 December 2020 / Published online: 18 January 2021

(C) IPNA 2021

Keywords Child $\cdot$ Hematuria $\cdot$ Kidney stones $\cdot 6$-amino-2,8-purinedione

A 13-month-old boy was admitted with red-brown spots on his diaper. He was a term infant born $3600 \mathrm{~g}$ and there was no prenatal feature in his history. His mother and father were first degree cousins; none of the family members had any kidney disease. His height was $79 \mathrm{~cm} \mathrm{(50-75 \% )}$ and weight $10.1 \mathrm{~kg}(25-50 \%)$. There was no abdominal tenderness on palpation. Physical examination was unremarkable. His laboratory examination results were as follows: blood urea nitrogen $9.7 \mathrm{mg} / \mathrm{dL}(N$ : 9-23 mg/dL), serum creatinine $0.17 \mathrm{mg} / \mathrm{dL}(N<0.5)$, sodium $141 \mathrm{mEq} /$ L ( $N$ : 136-145), potassium $4.7 \mathrm{mEq} / \mathrm{L}(N: 3.5-5.1)$, calcium $10.2 \mathrm{mg} / \mathrm{dL}(N: 9.0-11.0)$, phosphorus $5.1 \mathrm{mg} / \mathrm{dL}(N$ : 2.5-5.5), magnesium $2.2 \mathrm{mg} / \mathrm{dL}$ ( $N$ 1.7-2.5), bicarbonate $23.1 \mathrm{mmol} / \mathrm{L}(N: 20-31)$, and serum uric acid $3.6 \mathrm{mg} / \mathrm{dL}$ (N: 3.4-7.0). On urinalysis, pH 5, density 1017 , protein trace, hemoglobin $2+$, and 132 erythrocytes/HPF were seen on microscopic analysis of the sediment. On ultrasonography, 3-4 hyperechogenic stones, the largest having a diameter of $6 \mathrm{~mm}$ on the middle and upper calyces of the left kidney and a stone with a diameter of $5 \mathrm{~mm}$ on the middle calyx of the right kidney, all having echogenic twinkling

The answers to these questions can be found at https://doi.org/10.1007/ s00467-020-04910-y4.

Mustafa Koyun

mkoyun@akdeniz.edu.tr

1 Faculty of Medicine, Department of Pediatrics, Division of Pediatric Nephrology, Akdeniz University, 07070 Antalya, Turkey

2 Faculty of Medicine, Department of Pediatrics, Molecular Medicine Laboratory, Ege University, Izmir, Turkey artifact were seen. No radiopaque stone was found on abdominal X-ray. Urine calcium/creatinine was $0.1 \mathrm{mg} / \mathrm{mg}$ $(N<0.6)$, urine oxalate/creatinine: $0.02 \mathrm{mg} / \mathrm{mg}(N<$ $0.11)$, urine uric acid/creatinine: $0.84 \mathrm{mg} / \mathrm{mg}(N<1.9)$, urine magnesium/creatinine: $0.15 \mathrm{mg} / \mathrm{mg}(N>0.13)$, and urine citrate/creatinine: $1.41 \mathrm{mg} / \mathrm{mg}(N>0.42)$. Urinary excretion of cystine was also within normal ranges. A therapy with potassium citrate in addition to hydration and dietary recommendations were given. On follow-up ultrasonographic evaluations, an increase in the number of stones was detected. A kidney computerized tomography scan done at the age of 3.5 years showed 7-8 stones in the renal pelvis (the largest having a diameter of $5 \mathrm{~mm}$ ) and 4 5 stones on the lower calyx (the largest having a diameter of $5 \mathrm{~mm}$ ) on the left kidney, 3-4 stones in left distal ureter (the largest having a diameter of $4 \mathrm{~mm}$ ) and two stones with $2 \mathrm{~mm}$ in the bladder. Afterwards, a percutaneous nephrolithotomy operation was performed, in which a large number of milimetric stones were removed. Chemical analysis of the stones yielded 6-amino-2,8purinedione.

\section{Questions}

1. What is your preliminary diagnosis?

2. Which exam would you want to elaborate the diagnosis?

3. How should this patient be managed?

Publisher's note Springer Nature remains neutral with regard to jurisdictional claims in published maps and institutional affiliations. 